first rebleed within the first two days following admission. It therefore seems that a lesion that has not bled for two days is unlikely to bleed again in the near future.

This finding raises the possibility of limiting the period of stay in hospital of patients with acute gastrointestinal bleeding. At present this period is commonly two to three weeks even in those not requiring emergency surgery. In the present study only one patient during a three-year period rebled for the first time later than the fifth day after admission, and in this case the haemorrhage was a terminal event in a subject admitted in hepatic coma, so that there could not have been any question of an early discharge from hospital. These findings suggest that no risk would be entailed by discharging from the sixth day onwards patients who have not shown any evidence of rebleeding, so long as there is no other indication for keeping them in hospital.

It is often difficult to decide whether to admit a patient who has been passing melaena stools for several days, is feeling well, and is not anaemic. The present investigation suggests that this is not necessary, since no patient admitted three or more days after the initial bleed with a haemoglobin level of more than $9 \mathrm{~g} / 100 \mathrm{ml}$ subsequently rebled.

A method of selecting patients for emergency investigation by barium meal examination or gastroscopy is needed (Truelove and Reynell, 1963), since such investigation of all patients throws an unnecessary burden on the $x$-ray department, with the necessity in some cases of cancelling routine booked examinations. In this context it is worth noting that patients admitted after a haematemesis are at considerably greater risk of recurrent haemorrhage than those admitted after melaena only.

I wish to thank Miss Margaret White for her help in collecting data for this study, Sir Francis Avery Jones for advice and encouragement, and Professor R. Doll for statistical advice.

\section{References}

Fraenkel, G. J., and Truelove, S. C. (1955). British Medical fournal, 1, 999. Jones, F. A. (1943). British Medical fournal, 1, 689

Jones, F. A. (1947). British Medical fournal, 2, 441, 477.

Jones, F. A (1956), Gastroenterology, 30, 166.

Jones, F. A., Gummer, J. W. P., and Lennard-Jones, J. E. (1968). Clinical Gastroenterology, 2nd edn., p. 548. Oxford, Blackwell Scientific.

Langman, M. J. S., and Doll, R. (1965). Gut, 6, 270.

MacLean, K. (1962). Medical Treatment, 2nd edn., p. 236. London, Churchill

MacLean, K. (1962). Medical Treatment, 2nd edn., p.

Northfield, T. C. (1970). Cambridge M.D. Thesis.
Northfield, T. C., and Smith, T. (1967). Gut, 8, 634

Northfield, T. C., and Smith, T. (1967). Gut, 8, 634.
Northfield, T. C., and Smith, T. (1970). Lancet, 2, 584.

Northfield, T. C., and Smith, T. (1970). Lancet, 2, 584.

chiller, K. F. R., Truelove, S. C., and Williams, D. G. (1970). British Medical fournal, $2,7$.

Tanner, N. C. (1950). Proceedings of the Royal Society of Medicine, 43, 147. Tibbs, D. J. (1956). Lancet, 2, 266.

Truelove, S. C., and Reynell, P. C. (1963). Diseases of the Digestive System, p. 220. Oxford, Blackwell Scientific.

Tudhope, G. R. (1958). Quarterly Fournal of Medicine, 27, 543.

\title{
PRELIMINARY COMMUNICATIONS
}

\section{Induction of Therapeutic Abortion by Intra-amniotic Injection of Urea}

\author{
J. O. GREENHALF， P. L. C. DIGGORY
}

British Medical fournal, 1971, 1, 28-29

\section{Summary}

A new method of mid-trimester termination of pregnancy is described in which intra-amniotic urea was used. The mean interval between intra-amniotic injection and abortion was 59 hours and the mean length of hospital stay six days; the feto-maternal haemorrhage incidence was one out of 10 cases, which compares favourably with other methods. No complications have yet been encountered.

\section{Introduction}

The increasing demand for termination of pregnancy has inevitably led to delay in appointments for gynaecological outpatient clinics and admission to hospital. Because of this more patients need their pregnancy terminated in the midtrimester, when a vaginal procedure may be very hazardous. In our view hysterotomy is the method of choice whenever sterilization is to accompany termination. We believe, however, that the inevitable uterine damage and possible weakness should be avoided when future child-bearing is a possibility.

Kingston Hospital Kingston-on-Thames, Surrey

J. O. GREENHALF, F.R.C.S., M.R.C.o.G., Senior Registrar P. L. C. DIGGORY, F.R.C.S., M.R.c.o.G., Consultant
Intrauterine injections, via the cervix, of soapy pastes of the Aretus/Utus type have been used since the 1930s, and Barns (1947) enthusiastically reported a success rate of $80 \%$ with a specially prepared soap paste in a series of 71 patients. Complications were limited to mild pyrexia and blood loss in only a few cases. Use of Utus paste was favourably described by Lachelin and Burgess (1968), who were successful in all of the 182 cases, and only $13(7 \%)$ developed a pyrexia requiring antibiotics. We have abandoned this method, however, after five severe pelvic infections in the last 20 terminations, two of which developed Escherichia coli septicaemia.

Amniocentesis and the injection of $50 \%$ dextrose has been used with great success by Brosset (1958) and Lewis et al. (1969), but there remains the potential hazard of intrauterine infection and the possibility of thromboembolic complications if, in error, part of the injection is made intravenously.

The injection of $20 \%$ hypertonic saline has been more widely used than glucose (Turnbull and Anderson, 1965; Csapo, 1966-7; Menzies and Hawkins, 1968). The method is both effective and convenient, but maternal deaths have $\mathrm{\omega}$ occurred, and Wagatsuma (1965) reported 25 deaths in Japan between 1946 and 1952. It may be significant that most of the deaths were associated with $30 \%$ saline rather than the $20 \%$ \& concentration. Cameron and Dayan (1966) also reported two deaths-one patient had been given a general anaesthetic, and in the other case twice as much hypertonic saline had been injected as liquor aspirated. Post-mortem findings showed $\stackrel{\Omega}{\mathbb{D}}$ acute haemorrhagic infarction of the amygdaloid nucleus and adjacent structures and also a Y-shaped infarct in the pons, thought to be due to excessive cerebral dehydration following inadvertent intravenous or intraperitoneal injection of $20 \%$ saline.

Study of these reports suggests that failures of technique may have been a main feature of the hypertonic saline deaths. In considering alternatives to saline on theoretical grounds urea seemed the safest possible substance, and we decided to try the induction of abortion with intra-amniotic 
urea, on the basis that an inadvertent intravenous or intraperitoneal injection would be far less likely to have harmful effects. High doses of urea (up to $1.5 \mathrm{~g} / \mathrm{kg}$ body weight) have been given by rapid intravenous injection in the past for the treatment of cerebral oedema and with no fatality (Birch, 1967). Ten patients have undergone termination so far in the mid-trimester with intra-amniotic urea injection.

\section{Patients and Methods}

In general we have preferred the vaginal route for termination up to about the 12th week in nulliparous women and about the 14th week in multiparae. In our series of intraamniotic terminations with urea the mean gestational age was 17.8 weeks, calculated from the first day of the last menstrual period. Our technique was to make certain that the patient had voided urine immediately before being taken to the operating theatre. A premedication of Valium (diazepam) 10 $\mathrm{mg}$ and Fortal (pentazocine) $30 \mathrm{mg}$ was given intravenously after the aspiration of $5 \mathrm{ml}$ of blood, which was taken for blood urea estimation. The abdomen was swabbed with chlorhexidine in spirit, the suprapubic stab area being surrounded by sterile drapes. A suprapubic stab incision was made with a prepacked sterilized $14-\mathrm{cm}$ length cannula having a cannula diameter of $2 \mathrm{~mm}$ O.D. and $1.5 \mathrm{~mm} \mathrm{I.D.,} \mathrm{the}$ area having previously been anaesthetized down to the peritoneum with 2"' plain lignocaine. Once the needle was definitely in the amniotic cavity and liquor was emerging the needle was withdrawn, leaving a polyethylene cannula carefully placed within the amniotic cavity. Then $200 \mathrm{ml}$ of liquor was drained off by attaching the polyethylene cannula to a further length of polyethylene tubing which drained liquor into a measuring bowl placed below the level of the uterus.

In one case in which it was not possible to obtain quite the full $200 \mathrm{ml} 80 \mathrm{~g}$ of Ureaphil was dissolved in $210 \mathrm{ml}$ of $5 \%$ dextrose, this solution being slowly injected via the polyethylene cannula into the amniotic cavity; the cannula was then withdrawn and the stab puncture site was sprayed with Octaflex and covered with a sterile gauze swab. As soon as the patients had recovered from the premedication they were encouraged to be out of bed and active in the ward until uterine contractions began. The blood urea was determined four-hourly in the first five patients for the first 28 hours, and two-hourly in the next five patients for the first 10 hours. Blood was also taken within one hour of abortion for maternal fetal cell counts, these being determined by a modified Kleihaucr technique.

One patient at 18 weeks had required a second intra-amniotic injection of Ureaphil 90 hours after the first injection because of no uterine contractions. She rapidly aborted within 10 hours of the second injection. The injection-abortion interval of 100 hours in this patient was calculated from the time of the first intra-amniotic injection. Details of the age of the patients, parity, and gestation times, together with intraamniotic injection abortion intervals and length of inpatient stay are shown in the Table.

No patient required antibiotics, there being no case of pyrexia. No patient required a blood transfusion or was curettage actually ncccssary. Only one patient, who was 18 weeks pregnant, had fetal cells in the maternal circulation, her blood group being A rhesus-positive.
Details of 10 Paticuts Who had Termination by the Intra-amiotic Injection of $80 \mathrm{~g}$ Ureaphil

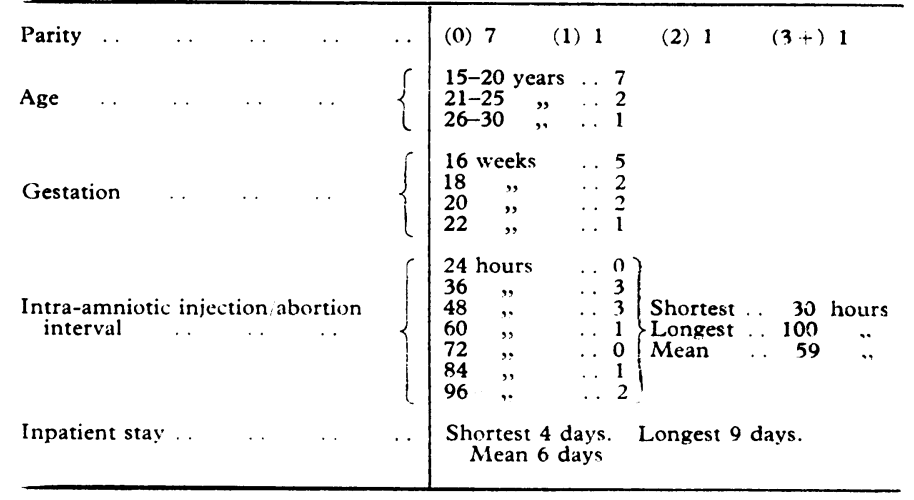

\section{Discussion}

Though our series is very small, it is apparent that intraamniotic urea is an effective method of terminating a midtrimester pregnancy and since on theoretical grounds it may be expected to be safer than using $20 \%$ saline we felt that a preliminary report on the method was justified. No patient required blood, antibiotics, or uterine curettage. The inpatient stay was similar to that in terminations in patients we have reated with saline, and the feto-maternal haemorrhage of $10 \%$ compares favourably with that of the saline group and with that described by Walsh and Lewis (1970). In our last 48 vaginal terminations of pregnancy in which fetal cell counts were performed, the incidence of feto-maternal haemorrhage was five cases $(10 \%)$, which again compares favourably with the figures of Voigt and Britt (1966), who gave a 9\%, incidence of feto-maternal haemorrhage in vaginal terminations of less than 12 weeks' gestation, and of $40 \%$ incidence in pregnancies above 12 weeks' gestation terminated by the vaginal route.

The mode of action of urea in causing abortion is not understood. Unlike saline it is rapidly disseminated in the body, as we have in fact confirmed by the maternal urea levels. We have found no correlation between the rise in blood urea and the injection-abortion interval. Far higher doses of urea have been given in the past for the temporary treatment of cerebral oedema without serious consequences, and therefore we feel that the levels of urea found are not hazardous to the patient, and have shown that it rapidly falls to normal.

\section{References}

Barns, H. I1. 1: (1947). Lancet, 2, 825 .

Birch, C. A. (1967). Emcrgencios in Medical Practice, sth edn. Edir.burgh, Livingstone.

Brosset, A. (1958). Acta Obstctricia et Gynecologica Scandinarica, 37, 519 Cameron, J. M., and Dayan, A. D. (1966). British Medical fournal, 1, 1010. Csapo, A. I. (1960-7). Year Book of Obstetrics and Gynecology', p. 126. Csapo, A. I. (1960-7). Year Book of Obstetrics and Gynecology, p. 126.
Lachelin, G. C. L., and Burgess, D. E. (1968). Fournal of Obstetrics and
Gynaecology of the British Commoni.ealth

Gynaecology of the British Commonwealth, 75, 1173 .
Lewis, B. V., Smith, J. W. G., and Speller, D. C. E. (1969). Fournal of Obstetrics and Gynaecology of the British Commontealth, 76, 1008 .
.

Menzies, D. N., and Hawkins, D. F. (1968). Fournal of Obstetrics and Gynaccology of the British Commonacalth, $75,215$.

Turnbull, A. C., and Anderson, A. B. M. (1965). Fournal of (obitetrics and Gynaecology of the British Commonivealth, $72,755$.

Voigt, J. C., and Britt, R. P. (1969). Britist: Aedical fournal, 4, 395.

Walsh, J. J., and Lewis, B. V. (1970). Fonrmil of Obstetrics and Gynaecology

Wagatsuma, $T$. (1965). American fournal of (Jhatctrics and Gynccoiogy, 93, 743. 